\title{
AN EXPLORATORY STUDY OF ENTREPRENEURIAL CENTERS IN PAKISTAN: AN UNTAPPED MARKET OPPORTUNITY
}

\author{
Dr. Shahid Qureshi1 \\ Director, Center for Entrepreneurial Development IBA Karachi \\ Dr. Farooq-E-Azam Cheema ${ }^{2}$ \\ Dean Faculty of Management Sciences at Bahria University Karachi \\ Sana Fawad ${ }^{3}$ \\ Research Assistant, IBA Center for Entrepreneurial Development IBA \\ Karachi
}

\begin{abstract}
Purpose:-Entrepreneurship has gained immense attention globally, especially amongst the academic world. Universities are transforming themselves into entrepreneurial universities by promoting industry academia linkages, opening offices of research and commercialization, opening up entrepreneurial centers and incubators and offering courses and workshops on entrepreneurship to inculcate an entrepreneurial mindset among the students, faculty and university administration. This phenomenon has also gained popularity in Pakistan. However, currently there is very limited research available on entrepreneurship education and promotion activities in Pakistan. This exploratory study investigates the state of entrepreneurship centers and entrepreneurship education in Pakistan.
\end{abstract}

Research Methodology:-A survey was conducted amongst the entrepreneurial centers in Pakistani universities inquiring about various activities happening on the university's campus. Multiple case design methodology is employed to analyze the data collected from nine entrepreneurial centers.

Findings:- With respect to entrepreneurial teaching, our study led us to the conclusion that modern pedagogical techniques are being gradually introduced at the universities. However, there is a need of such entrepreneurship courses that leverage indigenous entrepreneurial opportunities along with combining the individual skill set.

Practical Implications:- The survey results indicate that the state of entrepreneurship in Pakistan is in its early phases and needs a lot of attention from policy makers (on a macro level) and university administration (on a micro level) in order for the subject to blossom.

Keywords : Entrepreneurship, Entrepreneurship Centers, Entrepreneurship Development

\section{Jel Classification: D920, E220, F210}

\footnotetext{
* The material presented by the author does not necessarily portray the viewpoint of the editors and the management of the Institute of Business \& Technology (IBT)

1 Dr. Shahid Qureshi

2 Dr. Farooq-E-Azam Cheema

: squreshi@iba.edu.pk

: dr.cheema@live.com

3 Sana Fawad

: sanafawad@iba.edu.pk

(C) IBTJBS is published by the Institute of Business and Technology (IBT).

Main Ibrahim Hydri Road, Korangi Creek, Karachi-75190, Pakistan.
} 


\section{INTRODUCTION}

Entrepreneurship centers have assumed great significance for the impact it creates on new business development, technology commercialization and the career paths of students. The subject is reaching out at a rapid pace from the halls of business schools into other disciplines (Hanlon, 2010). As the evolution of this subject continued, universities began to initiate separate centers for the purpose of cultivating their in house "Entrepreneur", providing them with the facilities and networks to develop their own startups at the "Entrepreneurship Center". It helped the new startups in a wide range of activities ranging from research and idea generation to incubation and commercialization (Del-Palacio, et al., 2008).

Entrepreneurship has become a central component in economies across South East Asia. OECD figures show that firms that remain in business after the first two years have a $60-70 \%$ chance of surviving for at least five more years, They also encourage social cohesion and community development (OECD, 2004). Graduates who are either placed in jobs or are involved in their own setups play a pivotal role in the economic and social prosperity of the country. The governments in many countries have shown interest in entrepreneurship because of its relationship with regional economic development through new ventures and job creation (OECD, 1996). Further statistics show that small firms account for over $95 \%$ of all enterprises and employ between $60 \%-70 \%$ workers where women-owned businesses contribute up to a third of all SMEs (OECD, 2004). An indication in the progress of entrepreneurship is the growing number of entrepreneurship centers (Sandberg, 1991).

The purpose of this study is to compare and analyze the entrepreneurship centers and their activities in universities across Pakistan. Prior to this research, published data on the objectives, staffing, activities, incubation and future plans of the entrepreneurship centers in Pakistan did not exist.Although similar studies have taken place in different countries, this exploratory research is the first of its kind and gives a view of the evolution of entrepreneurial centers in Pakistan. Selvarajah \& Maslo (2005) conducted an exploratory study on Entrepreneurship Centers in Australian and New Zealand Universities. Menzies (2002) conducted a study on Entrepreneurship Education in US, Canada \& Denmark which compares and contrasts the models utilized in their respective universities. Bert Twaalfhoven (2006), conducted a comparative study on eight entrepreneurial centers of Entrepreneurship (3 US, 4 Europe, and 1 Russia). These centers serve as entrepreneurial hubs with different approaches.

Etzkkowitz (2004) discusses in detail the evolution of the entrepreneurial university and how it plays an important role. Marques (2006), presented his findings of the case study of the University of Coimbra on how university-industry-government interactions changed the innovation scenario in Portugal. Shane (2004), discusses the role university spinoff companies in wealth creation. Shinn (2002), presented his findings on the role of Triple Helix model and the production of knowledge. Chevalier (2005), discusses the Entrepreneurial orientation, technology transfer and spin-off performance of U.S. universities. 


\section{LITERATURE REVIEW}

The field of entrepreneurship is evolving at a rapid rate throughout the world. The number of universities offering entrepreneurship courses has grown from a handful to over 3000 today (Morris, et al., 2013). The degree of growth in this field can be evidenced by the fact that entrepreneurship research and development and full time faculty devoted to this study has grown exponentially. The number of academic journals devoted to the subject has also risen. The dimensions of this field are vast with some of the following as domain areas within entrepreneurship: Family Business Management, Social entrepreneurship, corporate entrepreneurship and Small business growth (Coviello et al., 2011; de Brion et al. 2006; Jones et al., 2011; Shane and Vekataraman, 2000).

Entrepreneurship as an educational subject has evolved beyond the misnomer that entrepreneurs are born, as there are some facets which can be cultivated and learned. "Most of the empirical studies indicated that entrepreneurship can be taught, or at least encouraged by entrepreneurship education" (Gorman, 1997). The number of universities offering courses is growing dramatically with many offering majors, minors, concentrations graduate degree programs in entrepreneurship. The more prestigious universities have even developed $\mathrm{PhD}$ programs to prepare the next generation of scholars and researchers. Much can be learned by reviewing the methodology applied in schools that have received recognition for their programs. Best practices can be reviewed include the Experiential Classroom program at the University of Florida, the Symposium for Entrepreneurship Educators at Babson College and Roundtable for Entrepreneurship Educators at Stanford University (Morris and Kuratko and Cornwall 2013). The major sources of information on this subject are present in academic journals, textbooks on entrepreneurship, books about entrepreneurship, bibliographies, autobiographies, case studies, newsletters, blogs, proceedings and conferences. Robinson and Hayes(1991) carried out a survey which had at least 10000 students to determine the extent of the growth in entrepreneurship. They deduced from their research that existing programs lacked both depth and integration. Their conclusion was that entrepreneurial education must include courses which focused on skill building with emphasis on negotiation, leadership, new product development, creative thinking and exposure to technological innovation. Further use of a dynamic set of tools such as computer simulations, behavioral simulations, student business startups, field trips and use of videos and films enhance the learning process. Their research helped them to discover that a methodological sequence of events must take place in the establishment of an entrepreneurship center. This involvesdefining the vision and objectives of the center, the strategic purpose for promoting awareness on entrepreneurialopportunities and triggering entrepreneurshipdevelopment (Mutsuddi, 2012). The study also revealed the importance of nurturing entrepreneurial skills through hands on experience rather than the textbook method. A summary of the findings is as follows:

- Increased use of experiential learning trying to create a real experience in entrepreneurship(Sherman, Sebora, Digman, 2008).

- Emphasis on practical skills in functional areas as often it is difficult for instructors to address the more abstract macro-level issues that new ventures face in growth. (Robinson, 2008). 
- $\quad$ Experiential learning activities such as networking and interviewing entrepreneurs develop real relationships which are essential components of entrepreneurship(Sherman,Sebora, Digman 2008).

One of the key activities at every university is the business plan competition. The competitions have four aims: to motivate students to come forward with their ideas, to build their commercial skills together with business talent, to attract venture capitalists, and to identify service providers who are willing to support entrepreneurial activities. The leadership of the organization plays an integral role in ensuring success of the center. The advisory body should preferably be run by the head of the institute such as the Chairman/President and the Principal/Director. It is also important that representatives from the Government play an essential part in the advisory panel (Mutsuddi, 2012)both physically and virtually (online). The entrepreneurship centers' 'product packages' consist of a wider mix of services such as business plan competitions spaces and incubators (Del-Palacio, et al., 2008).

According to Menzes (2002) an entrepreneurship center is defined as a designated unit within a university, or organization affiliated with a university which has an entrepreneurship related mandate. The literature review identified the following key variables which need to be known to identify the performance of entrepreneurial centers.

- The presence of an entrepreneurship center, its vision, team allocation and governance.

- The teaching methodology, syllabus content and faculty skills.

- Resources allocated towards faculty development

- Research activities and facilities provided at the center.

- Incubator services and supporting infrastructure for networking and funding purposes.

- Extracurricular activities\& outreach programs

- Collaboration and future endeavors

\section{METHODOLOGY}

The study has been carried out using multiple case design methods whereby questionnaire/survey as well as document analyses were employed followed by indepth discussions and interviews of the center managers / faculty. Our research included nine main questions which were then divided into sub questions to extract details on the main topics. The questionnaire started with whether the entrepreneurshipinitiatives in the university were being conducted by a separate entrepreneurship center or whether it was part of a department. In addition, we wanted to find out the vision of the centers leadership and what courses were being offered, the teaching methodology, and the faculty development programs to prepare entrepreneurship faculty. The emphasis on research, incubator spaces, funding facilities and advisory services present at the institute was also investigated. The final few questions pertained to the outreach and extracurricular activities, collaboration and future programs.

We retrieved the list of universities/institutions present in Pakistan from the HEC (Higher Education Commission) website from which shortlisting was carried out based on the Entrepreneurship activities being carried out by the entrepreneurial centers. Out of 83 universities/institutes, ten of them had a designated entrepreneurship center from 
which we were able to collect detailed questionnaires from nine. The initial results indicated that one institutehad recently started the entrepreneurship center as a supplement to their executiveeducation center and had yet to commence any entrepreneurial activity. Another two universities were in the process of initiating their program and have advertised for administrative staff for the center. This adds up to three institutes which have yet to make a fully developed program.

\section{RESULTS AND DISCUSSION}

\subsection{Entrepreneurial Centers}

The entrepreneurial phenomenon is independent of the business schools and requires a different mindset that defies the standard business practices suitable for large businesses and corporations. The experience to leverage the business schools to encourage and promote entrepreneurship has invariably failed as the faculty mindset is geared towards large businesses and corporations (Barney, 2010) (McCormack, 1986). IBA Karachi and NUST are one of the earlier universities that started working on the creation of entrepreneurial centers followed by others as mentioned in Table 1. Most of these centers have incorporated the spirit of societal value by mentioning this factor in the vision of the center. The total number of faculty/team allocated to the center ranges from 9 to 23, with 9 being the number of individuals present at university of Central Punjab and IBA Sukkur and 23 present at NUST and IBA. There are a limited number of centers that have a formal governing board to guide them on strategic planning. NUST has a selection committee which comprises of entrepreneurs to evaluate the business idea before giving them incubation space. The Entrepreneurial centers at Lahore University of Management Sciences (LUMS) and Baluchistan University of Information, Technology, Management and Sciences (BUITMS) are still in the very early phase of development. (See Table 1)

\subsection{Entrepreneurship Teaching}

One of the key responsibilities of an entrepreneurial center is to promote entrepreneurship by offering courses and short workshops on entrepreneurship to create an interest and develop an entrepreneurial mindset of the students. Pakistani universities are lagging in this aspect and in general many universities have started teaching generic entrepreneurship courses to their business and non-business students. The universities surveyed employed a variety of teaching techniques having a focus on the traditional teaching methodology and a few of them are using experiential learning, business plan competitions and the case study method. (See Table 2)

\subsection{Faculty Development}

At present, the entrepreneurship teaching method is in its infancy in Pakistan. The faculty members responsible for teaching entrepreneurship are mostly focused on the traditional approach in which the key learning at the completion of the course is developing a business plan. The use of modern entrepreneurship pedagogical techniques and experiential learning are still to be employed. Our results concluded that this area needs a lot of attention. Initiatives were taken by IBA CED and NUST TIC to enhance the skill level through training programs specifically designed for this purpose. NUST TIC has a separate training center which caters to the need of management, information 
technology and engineering students. (See Table 3)

\subsection{Research}

Entrepreneurship research helps identify the areas which need to be focused while teaching entrepreneurship. Local case studies inculcate a high level of interest among students and provide them with role models which they can relate to. An IBA CED led consortium of 8 universities has successfully developed three cycles of GEM (Global Entrepreneurship Monitoring) research on Pakistani cases. This pioneering work was carried out to understand the state of entrepreneurship in the country and indigenize best practices within the Pakistani context. More than 50 cases in entrepreneurship have been developed at IBA CED. University of Central Punjab has taken the initiative of writing case studies. (See Table 4)

\subsection{Incubator \& Resources}

The entrepreneurship centers' 'product packages' consist of a wider mix of services such as business plan competitions, forums for entrepreneurs and professionals and incubators (Del-Palacio, et al., 2008). Incubators play a significant role in promoting entrepreneurship. NUST TIC is one of the first university incubators in Pakistan followed by UMT, IBA Karachi, LUMS and IBA Sukkur. These incubators facilitate the new startups by providing them office space, faculty counseling, and advisory and legal services. Universities provide linkages with industry personnel who act as mentors and if the idea is noteworthy, they are prepared to fund a fraction of the startup. (See Table 5)

\subsection{Extra-Curricular Activities}

Educators increased use of experiential learning in the classroom reflects a desire to move away from traditional teaching methods such as text and lectures, particularly given the challenges of trying to create a real experience in entrepreneurship (Sherman, et al., 2008). This area is the least explored in Pakistan while it is considered to be the most effective methods of inculcating the entrepreneurial mindset through the process of experiential learning. IBA CED and NUST have been conducting national level business plan competitions for the past 3-4 years. LUMS, FAST and GIKI have started similar programs which span over a period of time inviting students from different institutions to participate. A detailed list of extra curricula activities is listed below in Table 6.

\subsection{Collaboration}

Sponsorship also entails making financial contributions to the cost of the program's infrastructure, prize money, and public-relations activities. If the sponsor is a government body, it is not likely to foot the whole bill, so collaboration between the public and private sectors is needed (Dodt, et al., 1999). Collaboration with international universities and institutes help in the learning process and gives access to the best practices. Pakistani universities have to go a long way in developing national and international collaborations at a global level. (See Table 7) 


\section{CONCLUSION}

This study has concluded that the numbers of centers are few i.e. only nine out of one hundred and forty universities have entrepreneurship centers. In addition, the total number of faculty members dedicated to each center was very limited and most centers were under resourced. With respect to entrepreneurial teaching, our study led us to the conclusion that modern pedagogical techniques are being gradually introduced at the universities. However, there is a need of such entrepreneurship courses that leverage indigenous entrepreneurial opportunities along with combining the individual skill set. There is dearth of foreign qualified $\mathrm{PhD}$ Entrepreneurship faculty members, leading to a significant supply demand gap at universities.

The amount of research carried out in this field is limited as compared to the number of universities offering courses. The incubation phenomenon is in its initial stages in Pakistan, going back a period of three years. Universities offering incubation centers provide supplementary services such as legal, advisory, networks, infrastructure facilities and in some cases funding.

Extracurricular activities have picked up at an exponential rate across Pakistan with universities carrying out business plan competitions at a regional and national level. Some of the more popular ones are, YLES, INVENT, DICE and Discover etc. This encourages idea promotion and allows students to gain confidence in pitching their startups to experts. Outreach activities are limited and few universities have international collaborations.

\section{RECOMMENDATIONS}

The policy makers and the university administration need to be apprised of the importance of entrepreneurship centers within universities. The universities have to focus on developing independent entrepreneurial centers to promote entrepreneurship in other schools i.e. engineering, agriculture, veterinary sciences and social sciences. Detailed recommendations are as follows:

\subsection{Entrepreneurship Centers}

- $\quad$ There should be an increase in the number of entrepreneurship centers as there are only nine centers across Pakistan.

- $\quad$ Faculty members from various disciplines should be deputed and trained for the purpose of educating students on a wide variety of skills.

- The entrepreneurship centers should report to the VC of the university in order to increase visibility and accountability.

- $\quad$ More number of people from the industry needs to be hired in the governing board to translate their vision to potential students and aid them in funding.

\subsection{Teaching}

- $\quad$ Educators should provide a wide assortment of cases to students that teach skills pertaining to entrepreneurial marketing, entrepreneurial finance, negotiation and networking. This would equip them with the necessary toolset in creating their own startup.

- Teachers should collaborate with industry personnel to write cases on their 
success stories and publish them in reputed journals. A variety of indigenous cases need to be taught as well, which would allow students to learn the workings of the local environment.

- $\quad$ Entrepreneurship course shall be made compulsory for all students.

\subsection{Faculty development}

- $\quad$ Entrepreneurship development training programs shall be conducted for faculty and budding entrepreneurs. HEC and university admin should take the initiative of devising such programs.

- $\quad$ Faculty should participate in research activities by identifying problems and challenges being faced by entrepreneurs.

- $\quad$ Furthermore, students should be encouraged to pursue a Masters and PhD in entrepreneurship to develop a pool of entrepreneurship faculty.

\subsection{Business Incubators}

- Business accelerator programs will help new startups by giving them a boost in their business. This has been introduced in very few universities and there remains a huge potential for such initiatives.

- Develop consulting clinics where the new business can address grievances and develop networks access to resources and marketing activities.

\subsection{Outreach Activities and Collaboration}

- $\quad$ The universities and entrepreneurial centers need to plan various outreach activities to leading to social entrepreneurship as this will result in a contribution to society.

- $\quad$ Collaboration with leading entrepreneurial universities and organizations like USASBE and AOM can be beneficial in knowing about the latest development in entrepreneurship teaching and research.

- $\quad$ The entrepreneurship educators shall form an Academy of Entrepreneurs in Pakistan. This would provide a collaborating platform for them to discuss ideas and share resources.

- The entrepreneurial mindset needs to be translated from the scholars to the students using a variety of approaches such as experiential learning and applied research.

\section{ACKNOWLEDGEMENT}

First of all with a profound gratitude, we are thankful to Almighty Allah forgiving us success, knowledge and understanding without which we would not been capable of completing this research paper.

We are also profoundly grateful to all our family members whose endurance and understanding have played a significant role in our success by sacrificing the important family time and supporting us all over the research work.

We are finally thankful to the editor, reviewers and IBT specially who provided us with the opportunity to publish our research paper in this esteemed journal. 


\section{REFERENCES}

Babson College, Frontiers of Entrepreneurship Research (series of volumes, Wellesley, MA; Babson College (1981-2012).

Barney, J., Clifford. (2010). What I Didn't Learn in Business School: How Strategy Works in the Real World Hardcover. Harvard Business Review Press (October 12, 2010)

Bert Twaalfhoven. (2006). A Study of 8 Centers of Dynamic Entrepreneurship. A Comparative Study Presented at the 10th Annual Conference of the German Speaking Professors and Universities on Entrepreneurship. www.efer.nl Chevalier, Arnaud; Oshea, Rory P; Allen, Thomas J; Roche, Frank. (2005). Entrepreneurial Orientation, Technology Transfer and Spin-off Performance of U.S. Universities, Research Policy, 34(7), 994-1009.

Coviello, N.E., McDougall, P.P and Oviatt, B.M. (2011). The Emergence, Advance and Future of International Entrepreneurship Research-An Introduction to the Special Forum, Journal of Business Venturing, 26(6).

Del-Palacio, I., Sole, F. \& Batista-Foguet, J. M., 2008. University entrepreneurship centres as service businesses. Service Industries Journal, Sep/Oct, 28(7/8), 939951.

Dodt, A., Stein, L. \& Strack, S., 1999. Do-it-yourself Silicon Valley: Using business plan competitions to spur innovation. McKinsey Quarterly, Issue 3, 60-69.

Gorman, G. H. D. \&. K. W., 1997. Some research perspectives on entrepreneurship education, enterprise education and education for small business management: a ten-year literature review. International small business journal, 15(3), 56-77.

Hanlon, B. P., 2010. Emerging trends in teaching entrepreneurship. Proceedings of the Marketing Management Association, 166-167.

Morris, M. H., Kuratko, D. F. \& Cornwall, J. R., 2013. Entrepreneurship Programs and the Modern University. s.l.:s.n.

Mutsuddi, I., 2012. Kickstarting Entrepreneurship Cells in Business Schools: Roadmap and challenge. Global Management Review, 6(4), 61-76.

Sandberg, W. \&. G. E., 1991. A profile of entrepreneurship research centers; orientation, interest, activities, and resources. Entrepreneurship Theory and Practice, Spring 15(3), 11-24.

Sherman, P. S., Sebora, T. \& Digman, L. A., 2008. Experiential entrepreneurship in the classroom: Effects of teaching methods on entrepreneurial career choice intentions. Journal of Entrepreneurship Education, Volume 11, 29-42. 


\section{APPENDIX}

\section{Table 1 \\ Detailed Information of Entrepreneurial Centers}

\begin{tabular}{|c|c|c|c|c|}
\hline University & Name of Center & $\begin{array}{l}\text { Vision of the } \\
\text { Entrepreneurship Center }\end{array}$ & $\begin{array}{c}\text { Team/Faculty Members } \\
\text { Allocated To The } \\
\text { Center } \\
\end{array}$ & $\begin{array}{l}\text { Governing Board } \\
\text { Details }\end{array}$ \\
\hline $\begin{array}{l}\text { IBA, } \\
\text { Karachi }\end{array}$ & $\begin{array}{l}\text { AmanCenter of } \\
\text { Entrepreneurial } \\
\text { Development (CED) }\end{array}$ & $\begin{array}{l}\text { To create wealth and value for } \\
\text { Pakistan by promoting } \\
\text { entrepreneurship and helping } \\
\text { entrepreneurs to work with } \\
\text { the right fusion of business } \\
\text { leaders, mentors and } \\
\text { entrepreneurial talent. }\end{array}$ & $\begin{array}{l}\text { i. Faculty (12) } \\
\text { ii. Entrepreneurship } \\
\text { Faculty (4) } \\
\text { iii. Manager/Staff etc. (4) }\end{array}$ & $\begin{array}{l}\text { IBA Director } \\
\text { (President) } \\
\text { Leading } \\
\text { Entrepreneurs from } \\
\text { Pakistan, US }\end{array}$ \\
\hline $\begin{array}{l}\text { Sukkur, } \\
\text { IBA }\end{array}$ & $\begin{array}{l}\text { Center for Entrepreneurial } \\
\text { Leadership and Incubation } \\
\text { (CELI) }\end{array}$ & $\begin{array}{l}\text { Promote entrepreneurship, } \\
\text { specifically social and } \\
\text { agriculture in rural areas of } \\
\text { Pakistan }\end{array}$ & $\begin{array}{l}\text { i. Faculty (2) } \\
\text { ii. Entrepreneurship } \\
\text { Faculty (4) } \\
\text { iii. Manager/Staff etc. (3) }\end{array}$ & Yes \& Yes \\
\hline $\begin{array}{l}\text { UMT } \\
\text { Lahore }\end{array}$ & $\begin{array}{l}\text { Center for Entrepreneurship } \\
\text { and Innovation" (CENTIN) }\end{array}$ & $\begin{array}{l}\text { To oblige the society by } \\
\text { embracing the challenges } \\
\text { through a continuous } \\
\text { development of human capital } \\
\text { with most innovative and } \\
\text { creative ideas }\end{array}$ & $\begin{array}{l}\text { i. Faculty (3) } \\
\text { ii. Entrepreneurship } \\
\text { Faculty (3) } \\
\text { iii. Manager/Staff etc. } \\
(7,2)\end{array}$ & Not at the moment \\
\hline $\begin{array}{l}\text { University } \\
\text { of Central } \\
\text { Punjab }\end{array}$ & $\begin{array}{l}\text { Centre for Entrepreneurship } \\
\text { and SMEs (CESME) }\end{array}$ & $\begin{array}{l}\text { The vision of CESME is foster } \\
\text { the spirit of entrepreneurship } \\
\text { amongst the student of UCP to } \\
\text { the point where they start } \\
\text { viewing the option of self- } \\
\text { employment as a better career } \\
\text { alternative for themselves. }\end{array}$ & $\begin{array}{l}\text { Faculty: } 03 \text { permanent } \\
\text { and } 03 \text { part-time } \\
\text { Core faculty: } 02 \\
\text { Staff: } 01 \text { Research } \\
\text { Associate }\end{array}$ & $\begin{array}{l}\text { There is no governing } \\
\text { body as such. It is } \\
\text { solely governed by a } \\
\text { director. }\end{array}$ \\
\hline $\begin{array}{l}\text { NUST } \\
\text { Islamabad }\end{array}$ & $\begin{array}{l}\text { Technology Incubation } \\
\text { Center.(TIC) }\end{array}$ & $\begin{array}{l}\text { Innovation and } \\
\text { commercialization by } \\
\text { safeguarding intellectual } \\
\text { property while developing } \\
\text { linkages with industry }\end{array}$ & $\begin{array}{l}\text { i. Faculty (5) } \\
\text { ii. Entrepreneurship } \\
\text { Faculty (15) } \\
\text { iii. Manager/Staff etc. } \\
1 \text { Director } \\
2 \text { Deputy Directors } \\
5 \text { Managers } \\
15 \text { Staff }\end{array}$ & $\begin{array}{l}\text { We have a selection } \\
\text { committee in which } \\
\text { people from the } \\
\text { industry are included. }\end{array}$ \\
\hline IOBM & $\begin{array}{l}\text { Entrepreneurship and } \\
\text { Management Excellence } \\
\text { Center (EMEC) }\end{array}$ & $\begin{array}{l}\text { Within next } 5 \text { years: } \\
\text { - Have } 20 \% \text { of graduating } \\
\text { students as entrepreneurs. } \\
\text { - Have } 600 \text { new ventures } \\
\text { formed with a targeted } \\
\text { survival rate of } 30 \% \text { after one } \\
\text { year. }\end{array}$ & $\begin{array}{l}\text { Total: } 9 \\
\text { Faculty: } 5 \\
\text { Director: } 1 \\
\text { Consultant: } 1 \\
\text { Manager/faculty: } 1 \\
\text { Officer/Faculty: } 1 \\
\text { Staff: } 5 \\
\end{array}$ & $\begin{array}{l}\text { IoBM's selection } \\
\text { committee act as a } \\
\text { governing body. }\end{array}$ \\
\hline LUMS & $\begin{array}{l}\text { LUMS Center for } \\
\text { Entrepreneurship }\end{array}$ & $\begin{array}{l}\text { To become the largest } \\
\text { breeding ground for } \\
\text { sustainable, high-growth } \\
\text { and/or high-impact business } \\
\text { ventures in Pakistan }\end{array}$ & $\begin{array}{l}\text { Team: } 5 \text { members. } \\
\text { Faculty: Foundation } \\
\text { Council consisting of } 10 \\
\text { members }\end{array}$ & $\begin{array}{l}\text { LUMS Management } \\
\text { Committee, } \\
\text { Foundation Council. } \\
\text { Entrepreneurs are } \\
\text { enlisted in the } \\
\text { governing bodies. }\end{array}$ \\
\hline COMSATS & CUBATOR 1ne & $\begin{array}{l}\text { To be 'the 1st choice' of } \\
\text { entrepreneurs for a wide range } \\
\text { of business services and } \\
\text { facilities creating a beneficial } \\
\text { atmosphere. }\end{array}$ & Team: 4 members & $\begin{array}{l}\text { Advisory Board } \\
\text { Faculty } 2 \\
\text { Industry } 2 \\
\text { ORIC } 2\end{array}$ \\
\hline BUITMS & $\begin{array}{l}\text { Business Incubation and } \\
\text { Entrepreneurship Center } \\
\text { (BIEC) }\end{array}$ & $\begin{array}{l}\text { Not Available- To start in near } \\
\text { future }\end{array}$ & None & None \\
\hline
\end{tabular}


Table 2

Entrepreneurship Teaching

\begin{tabular}{|c|c|c|c|}
\hline University & $\begin{array}{l}\text { List of courses being offered in } \\
\text { Entrepreneurship }\end{array}$ & $\begin{array}{l}\text { Method of teaching i.e. lecture, case } \\
\text { method, experiential learning? }\end{array}$ & $\begin{array}{l}\text { Faculty } \\
\text { entrepreneurial } \\
\text { experience }\end{array}$ \\
\hline IBA & $\begin{array}{l}\text { Entrepreneurship. Entrepreneurial Marketing, } \\
\text { Entrepreneurial Finance, Developing } \\
\text { Entrepreneurial Opportunities, Foundations for } \\
\text { Management and Entrepreneurship, Social } \\
\text { Entrepreneurship, Family Business, } \\
\text { Technology Entrepreneurship, Women } \\
\text { Entrepreneurship } \\
\text { Agricultural Entrepreneurship }\end{array}$ & $\begin{array}{l}\text { Lectures, Case Studies, Field visits, } \\
\text { Entrepreneurial project }\end{array}$ & Yes \\
\hline $\begin{array}{l}\text { Sukkur, } \\
\text { IBA }\end{array}$ & $\begin{array}{l}\text { Entrepreneurial Marketing, Entrepreneurial } \\
\text { Finance, Entrepreneurial Leadership, } \\
\text { Family Business Management, Social } \\
\text { Enterprise Management, Creativity \& } \\
\text { Innovation, Agriculture Entrepreneurship }\end{array}$ & $\begin{array}{l}\text { Case study, Experiential Learning, Project } \\
\text { Based }\end{array}$ & Yes \\
\hline $\begin{array}{l}\text { UMT } \\
\text { Lahore }\end{array}$ & $\begin{array}{l}\text { Entrepreneurship } \\
\text { Managing Family Businesses Innovations } \\
\text { Management }\end{array}$ & $\begin{array}{l}\text { Lectures, Case Studies, Field visits, } \\
\text { Entrepreneurial project }\end{array}$ & Yes \\
\hline $\begin{array}{l}\text { University } \\
\text { of Central } \\
\text { Punjab }\end{array}$ & $\begin{array}{l}\text { Entrepreneurial Marketing, Entrepreneurial } \\
\text { Finance, Business Model Development, } \\
\text { Business Plan, Idea Generation \& Creativity, } \\
\text { New Product Development }\end{array}$ & $\begin{array}{l}\text { Lectures, case method and experiential } \\
\text { learning, depending upon the nature of the } \\
\text { course. In the business plan course, for } \\
\text { instance, most of the learning comes from } \\
\text { street testing the business model. }\end{array}$ & Yes \\
\hline $\begin{array}{l}\text { NUST } \\
\text { Islamabad }\end{array}$ & Entrepreneurship & Lecture, case studies, industry tours & Yes \\
\hline IOBM & $\begin{array}{l}\text { Two courses are offered in the BBA and MBA } \\
\text { program }\end{array}$ & $\begin{array}{l}\text { Lecture }(20 \%) \text {, Practical }(80 \%) \text {; case study, } \\
\text { industry tour }\end{array}$ & Yes \\
\hline LUMS & $\begin{array}{l}\text { Entrepreneurial Workshops are conducted in } \\
\text { which cover the following } \\
\text { Product, company, startup building, } \\
\text { entrepreneurial development, legal, } \\
\text { management, marketing, HR, administration, } \\
\text { documentation, online marketing, etc. }\end{array}$ & $\begin{array}{l}\text { Mentoring sessions, one to one scenarios, } \\
\text { Seminars, conferences, participation in events. }\end{array}$ & Yes \\
\hline COMSATS & $\begin{array}{l}\text { ILO training funded by HEC } \\
\text { How to start and improve your business } \\
\text { Legal issues for startups }\end{array}$ & Workshops, two way interaction & Yes \\
\hline BUITMS & Not available & Not available & Not available \\
\hline
\end{tabular}

Table 3

Faculty Development

\begin{tabular}{|l|l|}
\hline \multicolumn{1}{|c|}{ University } & \multicolumn{1}{c|}{ Entrepreneurship faculty development and training programs } \\
\hline IBA & $\begin{array}{l}\text { Faculty Development Workshops } \\
\text { Participant Centered Learning Pedagogy } \\
6 \text { faculty members attended the Babson Faculty Development Program in US }\end{array}$ \\
\hline Sukkur, IBA & Training of Trainers \\
\hline UMT Lahore & Training programs for faculty \\
\hline $\begin{array}{l}\text { University of } \\
\text { Central Punjab }\end{array}$ & None \\
\hline NUST Islamabad & Professional Development Centre for training \\
\hline IOBM & Training of Trainers \\
\hline LUMS & REDC is a complete training and development center which is one department of LUMS for such matters. \\
\hline COMSATS & The program manager was trained by ILO \\
\hline BUITMS & Not available \\
\hline
\end{tabular}




\begin{tabular}{|l|l|}
\hline \multicolumn{1}{|c|}{ University } & \multicolumn{1}{c|}{ Any involvement in entrepreneurship research and case writing? Please elaborate. } \\
\hline IBA & $\begin{array}{l}\text { GEM (Global Entrepreneurship Monitoring) Pakistan Project for 2011, 12 and 13 was carried out at IBA } \\
\text { Case Studies on Family Business, Entrepreneurship and Women Entrepreneurship }\end{array}$ \\
\hline Sukkur, IBA & Faculty and students actively involved in case study writing and research \\
\hline UMT Lahore & Not at present \\
\hline $\begin{array}{l}\text { University of } \\
\text { Central Punjab }\end{array}$ & $\begin{array}{l}\text { One of the entrepreneurship faculty members is currently working on a USAID-funded research project on } \\
\text { small and micro entrepreneurs of Lahore. Another faculty member has just completed the field work of } \\
\text { SMEs within the Automotive sector. }\end{array}$ \\
\hline NUST Islamabad & None \\
\hline IOBM & Yes IoBM faculty associated with EMEC is involved in research \\
\hline LUMS & $\begin{array}{l}\text { As LCE is a new establishment, we are in constant communication with our business school, specifically the } \\
\text { faculty of entrepreneurship. Our first batch startups are under research and their case studies are underway. }\end{array}$ \\
\hline COMSATS & Not yet \\
\hline BUITMS & Not available \\
\hline
\end{tabular}

\begin{tabular}{|c|c|c|c|c|}
\hline University & $\begin{array}{l}\text { No of Incubator Spaces } \\
\text { Available and No in use }\end{array}$ & $\begin{array}{l}\text { Duration of Incubation } \\
\text { Period }\end{array}$ & $\begin{array}{l}\text { Provision of Seed } \\
\text { funding or Angel } \\
\text { funding }\end{array}$ & $\begin{array}{l}\text { Incubation advisory } \\
\text { services }\end{array}$ \\
\hline IBA & $\begin{array}{l}\text { Incubator Space } 40 \\
30 \text { in use }\end{array}$ & Upto 1.5 to 2 years & $\begin{array}{l}\text { Seed Funding } \\
\text { Angel Funding }\end{array}$ & Yes \\
\hline $\begin{array}{l}\text { Sukkur, } \\
\text { IBA }\end{array}$ & 5 available, 4 in use & Max of 2 years & Case to Case & Yes \\
\hline $\begin{array}{l}\text { UMT } \\
\text { Lahore }\end{array}$ & One incubation room & $\begin{array}{l}\text { Not utilized at the } \\
\text { moment. }\end{array}$ & None & None \\
\hline $\begin{array}{l}\text { University } \\
\text { of Central } \\
\text { Punjab }\end{array}$ & $\begin{array}{l}\text { There is no incubation } \\
\text { facility yet. }\end{array}$ & None & None & Yes \\
\hline $\begin{array}{l}\text { NUST } \\
\text { Islamabad }\end{array}$ & $\begin{array}{l}30 \text { available and } 22 \text { in use } \\
\text { with more in the pipeline }\end{array}$ & $\begin{array}{l}\text { Evaluation period is } 6 \\
\text { months. On the selection } \\
\text { committee's approval, } \\
\text { they can stay for } 18 \\
\text { months. }\end{array}$ & $\begin{array}{l}\text { Connect them to related } \\
\text { personnel }\end{array}$ & $\begin{array}{l}\text { Yes and Business } \\
\text { Development Office }\end{array}$ \\
\hline IOBM & $\begin{array}{l}\text { Currently none } \\
\text { But by end 2015, } 20\end{array}$ & None & None & None \\
\hline LUMS & $\begin{array}{l}\text { Incubation: } \\
\text { In-house } 6 \text { teams x } 4 \\
\text { members } \\
4 \text { companies on } \\
\text { acceleration program: }\end{array}$ & 4 Months & Yes & Yes \\
\hline BUITMS & Not available & Not available & Not available & Not available \\
\hline COMSATS & $\begin{array}{l}30 \text { offices } \\
17 \text { are occupied }\end{array}$ & 24 months & yes & Yes \\
\hline
\end{tabular}


Table 6

Extra Curricular Activities

\begin{tabular}{|c|c|}
\hline Question & The range of Entrepreneurial Extra Curricular activities \\
\hline IBA & $\begin{array}{l}\text { Business Plan Competition } \\
\text { Rocket Pitch Competition } \\
\text { Summer Venture Program } \\
\text { Entrepreneurs in Residence } \\
\text { Brain Trust Mentorship } \\
\text { Networking Workshops } \\
\text { Entrepreneurship Speaker events }\end{array}$ \\
\hline Sukkur, IBA & Trainings, workshops, business plan competition \\
\hline UMT Lahore & Business Plan Competition, Yearly Entrepreneurial Festival, Session with Entrepreneurs \\
\hline $\begin{array}{l}\text { University of } \\
\text { Central Punjab }\end{array}$ & $\begin{array}{l}\text { Annual Youth Entrepreneurship Summit } \\
\text { Business Plan competitions } \\
\text { Meet the entrepreneur sessions } \\
\text { Case study competitions } \\
\text { Brand wars }\end{array}$ \\
\hline NUST Islamabad & $\begin{array}{l}\text { DISCOVER } \\
\text { PM entrepreneurial challenge-PAKATHON } \\
\text { Collaboration with MIT, Stanford University, LUMS and NUST }\end{array}$ \\
\hline IOBM & $\begin{array}{l}\text { Business Plan competitions } \\
\text { Summer Entrepreneurship Programs } \\
\text { Sessions with Entrepreneurs } \\
\text { Entrepreneurship society conducts mentoring sessions } \\
\text { Experiential learning projects } \\
\text { Business Simulation (TopSim) } \\
\text { Entrepreneurial experiential projects }\end{array}$ \\
\hline LUMS & $\begin{array}{l}\text { Slide deck competitions } \\
\text { Business pitch competitions } \\
\text { Mentoring sessions, Networking sessions, Seminars and workshops } \\
\text { Open house }\end{array}$ \\
\hline COMSATS & Workshops \\
\hline BUITMS & Not available \\
\hline
\end{tabular}

Table7

Collaboration with other universities

\begin{tabular}{|c|c|}
\hline Question & What are the national and international collaborations? \\
\hline IBA & $\begin{array}{l}\text { International } \\
\text { Babson, UK, Germany, ISB India } \\
\text { National } \\
\text { GOP, KCCI, LCCI etc. } \\
\text { MNCs } \\
\text { Local Consultants } \\
\text { Entrepreneurs } \\
\text { IBA Alumni }\end{array}$ \\
\hline Sukkur, IBA & Yes. With universities in Pakistan as well as abroad. \\
\hline UMT Lahore & National Collaborators at the moment \\
\hline $\begin{array}{l}\text { University of Central } \\
\text { Punjab }\end{array}$ & We have signed MoUs on different agendas with SMEDA, SME Business Support Fund and TiE Lahore \\
\hline NUST Islamabad & $\begin{array}{l}\text { International Collaborations: } \\
\text { MIT Enterprise Forum } \\
\text { Pakathon(MIT, Stanford, Tufts) } \\
\text { The Indus Entrepreneurs (TiE) } \\
\text { Global Innovation through Science and Technology (GIST) } \\
\text { National Collaborations: } \\
\text { Cambridge Advisors Network, IBA - Invent, Punjab IT Board, Plan } 9 \\
\text { PASHA, PSEB }\end{array}$ \\
\hline IOBM & $\begin{array}{l}\text { Yes: Association with International Supply Chain Education Alliance } \\
\text { Association with INJAZ, OPEN, Collaboration with Venture capitalist firms \& Investors } \\
\text { Caucus University, Georgia. }\end{array}$ \\
\hline LUMS & $\begin{array}{l}\text { International } \\
\text { India, USA. } \\
\text { National } \\
\text { Media, MNCs, Entrepreneurs, LUMS Alumni }\end{array}$ \\
\hline Collaboration & ICCI, RCCI (Islamabad and Rawalpindi chamber of commerce) \\
\hline BUITMS & Not available \\
\hline
\end{tabular}

